\title{
EFEK MONOSODIUM GLUTAMAT TERHADAP GAMBARAN HISTOLOGI HEPAR TIKUS PUTIH (Rattus norvegicus) GALUR WISTAR
}

\author{
Effects of monosodium glutamate on the histological description of the liver of wistar \\ white rats (Rattus norvegicus) \\ ${ }^{1}$ Shely Ayu Lestari, ${ }^{2}$ Dita Pratiwi Kusuma Wardani, ${ }^{3}$ Tantri Analisawati Sudarsono \\ ${ }^{1,2,3}$ Program Studi Teknologi Laboratorium Medik D4, Fakultas Ilmu Kesehatan \\ Universitas Muhammadiyah Purwokerto
}

Koresponden: shelylestari11@gmail.com/08884000701

\begin{abstract}
Monosodium glutamate (MSG) is a sodium salt of glutamic acid that naturally comes from vegetable and animal protein functioned as a taste enhancer. So far, the use of MSG in various countries has increased by $1 \mathrm{~g} /$ day and can have an impact on cell damage to several organs. The purpose of this study was to find out the effects of MSG on the liver histology of Wistar white rats (Rattus norvegicus). This study used Posttest Only Control Group Design consisting of 4 groups, as control and MSG treatment doses of $5 \mathrm{~g} / \mathrm{kg} \mathrm{BW}$, $10 \mathrm{~g} / \mathrm{kg} \mathrm{BW}$, and $15 \mathrm{~g} / \mathrm{kg} \mathrm{BW}$ for 14 days orally. Each group consisted of 6 male white rats (Rattus norvegicus) aged 2-3 months with a weight of 200-250 grams in good health. A day after 14 days of treatment, the rats' liver organs were taken and preparations were made using the paraffin method. Data were analyzed using the Kruskal-Wallis test. The results of research showed that the control group looked normal, while the P1 group had 40.5 (4043)\% cell abnormalities and 52.5 (27-56)\% cell abnormalities. The P3 group showed the most significant liver cell damage, namely 60 (59-62)\%. The results of the Kruskal-Wallis test analysis showed a significant difference of $p=0.034$ between cell abnormalities and the dose level of MSG ( $p$-value 0.05). It can be concluded that MSG administration in stratified doses can cause liver cell damage in the form of degeneration and necrosis. Giving a dose of MSG $15 \mathrm{~g} / \mathrm{kg} \mathrm{BW}$ for 14 days showed the most significant liver cell damage at 60 (59$62) \%$.
\end{abstract}

Keywords: Cell Abnormality, Liver, Monosodium Glutamate

\begin{abstract}
ABSTRAK
Monosodium glutamat (MSG) merupakan garam natrium asam glutamat yang secara alami berasal dari protein nabati maupun hewani dan memiliki sifat sebagai penegas rasa (taste enhancer). Selama ini penggunaan MSG di berbagai negara mengalami peningkatan \pm 1 $\mathrm{g} /$ hari dan dapat berdampak pada kerusakan sel terhadap beberapa organ. Tujuan penelitian ini untuk mengetahui efek pemberian MSG terhadap gambaran histologi hepar tikus putih (Rattus norvegicus) galur Wistar. Rancangan yang digunakan yaitu Postest Only Control Group Design yang terdiri atas 4 kelompok, sebagai kontrol dan perlakuan MSG dosis $5 \mathrm{~g} / \mathrm{kg}$ $\mathrm{BB}, 10 \mathrm{~g} / \mathrm{kg} \mathrm{BB}$, dan $15 \mathrm{~g} / \mathrm{kg}$ BB selama 14 hari secara per oral. Masing-masing kelompok
\end{abstract}

Vol. 12 No. 1, Juni 2021

DOI: https://doi.org/10.32382/mak.v12i1.2000 
terdiri atas 6 ekor tikus putih jantan (Rattus norvegicus) galur Wistar usia 2-3 bulan dengan berat 200 - 250 gram dalam keadaan sehat. Setelah 14 hari perlakuan dilakukan pengambilan hepar tikus dan pembuatan preparat histologi dengan metode paraffin. Data dianalisis dengan uji Kruskal-Wallis. Hasil penelitian menunjukkan bahwa kelompok kontrol tidak ada abnormalitas pada histologi hepar, sedangkan kelompok P1 ditemukan abnormalitas sel sebesar 40,5 (40-43)\% dan P2 abnormalitas sel sebesar 52,5 (27-56)\%. Kelompok P3 menunjukkan kerusakan sel hepar paling signifikan, yaitu sebesar 60 (59-62)\%. Hasil analisis uji Kruskal-Wallis menunjukkan adanya perbedaan signifikan $\mathrm{p}=0,034$ antara abnormalitas sel dengan tingkat dosis MSG ( $\mathrm{p}$ value < 0,05). Kesimpulan dari penelitian ini pemberian MSG dengan dosis bertingkat dapat menyebabkan kerusakan sel hepar berupa degenerasi dan nekrosis. Pemberian dosis MSG $15 \mathrm{~g} / \mathrm{kg} \mathrm{BB}$ selama 14 hari menunjukkan kerusakan sel hepar paling signifikan sebesar 60 (59-62)\%.

Kata Kunci: Abnormalitas Sel, Hepar, Monosodium Glutamat

\section{PENDAHULUAN}

Kemajuan teknologi dan informasi berdampak pada perubahan pola hidup masyarakat terutama dalam mengkonsumsi makanan cepat saji. Makanan cepat saji tidak memiliki nilai gizi untuk tubuh, namun memiliki kandungan gula cukup tinggi, dan mengandung bahan tambahan pangan yang membuat makanan menjadi lebih enak dan lezat (Pamelia, 2018). Bahan tambahan pangan (BTP) merupakan bahan yang ditambahkan ke dalam makanan untuk mempengaruhi sifat atau bentuk makanan. BTP terdiri atas pewarna, pemanis, penyedap rasa dan aroma, pengawet dan pengental (Nurdin \& Utomo, 2018). Penggunaan bahan tambahan makanan yang paling sering digunakan adalah Monosodium glutamat (MSG) (Maidawilis, 2010).

Monosodium glutamat (MSG) lebih dikenal dengan berbagai nama dagang seperti vetsin atau micin. MSG mengandung bahan kimia asam glutamat merupakan salah satu jenis asam amino dan menjadi bagian kerangka utama dari berbagai jenis protein makanan yang berasal dari nabati maupun hewani (Andriani, 2017). MSG dapat juga digunakan untuk menghilangkan rasa tidak sedap pada makanan tertentu seperti menghilangkan rasa tidak sedap pada masakan berbahan kentang (Tobi, 2013). Federation of American Societies for Experimental Biology (FASEB) menetapkan penggunaan MSG tidak lebih dari 3 gram/hari, sedangkan menurut WHO/FAO penggunaan MSG hanya diperbolehkan sebanyak $120 \mathrm{mg} / \mathrm{kg}$ BB/hari (Muntaza \& Annis, 2020).

Konsumsi MSG terbukti dapat mempengaruhi berbagai organ tubuh. Sukmaningsih et al. (2011) menyatakan bahwa pemberian MSG dosis $3 \mathrm{mg} / \mathrm{g}$ BB selama 35 hari dapat menurunkan jumlah spermatosit akibat stres oksidatif karena adanya radikal bebas (Sukmaningsih et al., 2011). Wasilah (2016) juga menyatakan bahwa pemberian MSG dosis 2,4 g/kg $\mathrm{BB} /$ hari dan $4,8 \mathrm{~g} / \mathrm{kg} \mathrm{BB} /$ hari selama \pm 14 hari, dapat menurunkan kadar ureum dan kreatinin ginjal secara signifikan karena gangguan filtrasi kreatinin (Wasilah, 2016). Didukung pula melalui pernyataan Rangkuti et al. (2012) bahwa pemberian MSG dosis $9 \mathrm{~g} /$ hari selama 14 hari dapat meningkatkan jumlah mikronukleus eritrosit (Rangkuti et al., 2012). Selain itu, 
Ermayanti et al. (2014) menyatakan bahwa pemberian MSG pada mencit jantan secara peroral selama 35 hari menunjukkan adanya kerusakan histologi hepar berupa degenerasi dan nekrosis sel. Degenerasi yang ditimbulkan berupa degenerasi lemak, degenerasi hidrofilik dan degenerasi bengkak keruh. Adapula pada nekrosis terdapat adanya inti yang mengalami piknosis, karioreksis dan kariolisis.

Didukung pula pada penelitian Andreas et al. (2015) bahwa pemberian MSG pada tikus (Rattus norvegicus) galur wistar galur wistar dosis $5 \mathrm{mg} / \mathrm{g}$ BB secara per oral dengan 3 periode berbeda, yaitu 28, 42, dan 56 hari kemudian dihentikan pemberian MSG dapat mengakibatkan terjadinya kerusakan hepatosit dan regenerasi sel setelah 14 hari pemberian MSG.

.Penelitian ini bertujuan untuk mengetahui efek MSG dosis $5 \mathrm{~g} / \mathrm{kg} \mathrm{BB}, 10$ $\mathrm{g} / \mathrm{kg} \mathrm{BB}$, dan $15 \mathrm{~g} / \mathrm{kg}$ BB terhadap gambaran histologi hepar tikus putih Rattus norvegicus Galur Wistar selama 14 hari perlakuan.

\section{METODE}

Penelitian ini dilakukan menggunakan metode true experimental dengan rancangan Postest Only Control Group Design. Sampel terdiri atas 4 kelompok, 1 kelompok sebagai kontrol tanpa pemberian dosis MSG sedangkan 3 kelompok lainnya mendapat perlakuan pemberian MSG dosis $5 \mathrm{~g} / \mathrm{kg} \mathrm{BB}, 10 \mathrm{~g} / \mathrm{kg}$ $\mathrm{BB}$, dan $15 \mathrm{~g} / \mathrm{kg} \mathrm{BB}$ yang dilarutkan dalam $3 \mathrm{ml}$ aquades selama 14 hari secara per oral. Masing-masing kelompok terdiri atas 6 ekor tikus jantan wistar. Teknik pengambilan sampel dilakukan secara Allocation Random Sampling. Sehari setelah 14 hari perlakuan dilakukan pengambilan organ hepar dan pembuatan preparat histologi menggunakan metode paraffin.

Penelitian dilaksanakan di Laboratorium Farmakologi Fakultas Kedokteran Universitas Muhammadiyah Purwokerto dan Laboratorium Terpadu Universitas Muhammadiyah Purwokerto pada bulan Juni-Agustus 2020.

Abnormalitas sel dianalisis dengan uji Kruskal-Walis, kemudian dilanjutkan uji post hoc Mann-Whitney U (Dahlan, 2009). Penelitian telah dilakukan dan mendapatkan persetujuan dari Komisi Etik Penelitian Kesehatan Universitas Muhammadiyah Purwokerto Nomor Registrasi: KEPK/UMP/06/VI/2020.

\section{HASIL}

Gambaran histologi hepar tikus putih (Rattus norvegicus) galur Wistar disajikan pada gambar 1. Berdasarkan Gambar 1. diketahui bahwa gambaran histologi hepar yang diamati dari 5 lapang pandang pada masing-masing kelompok antara lain, kelompok A (Kontrol) ditunjukkan dengan adanya bentuk hepatosit normal $(\mathrm{H})$ dan sinusoid $(\mathrm{S})$. Gambaran histologi hepar pada kelompok B (P1) ditunjukkan dengan adanya perubahan histologi hepar tikus berupa degenerasi lemak (DL) dan kongesti pada sinusoid (KS). Gambaran histologi hepar pada kelompok $\mathrm{C}(\mathrm{P} 2)$ ditunjukkan dengan adanya perubahan histologi hepar tikus berupa degenerasi hidropik (DH) dan karioreksis (KR). Gambaran histologi hepar pada kelompok D (P3) ditunjukkan dengan adanya perubahan histologi hepar tikus berupa piknosis (PIK) dan degenerasi lemak (DL).

Perbesaran ukuran sel hepar lebih banyak terdapat pada kelompok perlakuan daripada kelompok kontrol. Ada berbagai 
macam jenis MSG salah satunya MSG murni. MSG yang digunakan dalam penelitian ini adalah MSG murni. MSG terdiri atas beberapa unsur pokok, yaitu $78 \%$ glutamat, $12 \%$ natrium, dan $10 \%$ air (Maulina, 2018). Kandungan natrium dalam MSG tiap 1 sendok teh berkisar 492 mg (Menkes RI, 2014).

Abnormalitas sel hepar yang diamati dari 5 lapang pandang pada pemberian dosis MSG $0 \mathrm{~g} / \mathrm{kg}$ BB (kontrol) sebesar $0 \%$ menandakan normal. Abnormalitas sel hepar pada kelompok pemberian dosis MSG 5 g/kg BB sebesar 40,5 (40-43)\% menandakan kerusakan sedang. Abnormalitas sel hepar pada kelompok pemberian dosis MSG $10 \mathrm{~g} / \mathrm{kg}$ BB sebesar 52,5 (27-56)\% menandakan kerusakan besar. Abnormalitas sel hepar pada kelompok pemberian dosis MSG $15 \mathrm{~g} / \mathrm{kg}$ BB sebesar 60 (59-62)\% menandakan kerusakan besar. Hasil analisis uji Kruskal-Wallis menunjukkan adanya perbedaan signifikan antara abnormalitas sel dengan tingkat dosis MSG $\mathrm{p}=0,034$. Uji Post hoc Mann-Whitney U menunjukkan bahwa kelompok yang saling beda signifikan, antara lain kelompok kontrol dengan kelompok P1 sebesar $p=0,013$. Kelompok kontrol dengan kelompok P2 sebesar $\mathrm{p}=0,014$. Kelompok kontrol dengan kelompok P3 sebesar $\mathrm{p}=0,019$. Kelompok P1 dengan kelompok P3 sebesar $\mathrm{p}=0,032$. Kelompok P2 dengan kelompok P3 sebesar $\mathrm{p}=0,034$. Hanya kelompok P1 dan P2 yang tidak signifikan $(p=0,245)$.

\section{PEMBAHASAN}

Masyarakat sering menggunakan MSG sebagai penyedap rasa karena murah dan mudah didapat, namun MSG juga dapat membangkitkan selera makan. MSG yang digunakan pada penelitian ini merupakan MSG murni yang mengandung natrium sebanyak $492 \mathrm{mg}$ dalam satu sendok teh (Menkes RI, 2014). Kemampuan monosodium glutamat dalam meningkatkan transmisi impuls syaraf dapat membantu fungsi regulasi dan koordinasi jika digunakan secara optimal. Penggunaan yang berlebih mampu menyebabkan toksisitas pada hepar. Hal ini disebabkan karena hepar memiliki reseptor terhadap MSG sehingga rentan mengalami kerusakan akibat stres oksidatif (Johan et al., 2018; Maulina, 2018)

Gambaran mikroskopis histologi hepar kelompok kontrol menunjukkan abnormalitas sel sebesar 0\% hepatosit normal berbentuk poliglonal dan tidak ditemukan kongesti sinusoid. Hal ini sesuai dengan hasil penelitian Setiani et al. (2016), bahwa gambaran histologi hepar pada kelompok kontrol tanpa pemberian MSG selama 14 hari menunjukkan struktur lobulus hati normal berbentuk heksagonal, sel hati berbentuk poligonal, sitoplasma luas dan homogen serta tidak terjadi peradangan sel pada sinusoid. Selaras dengan penelitian yang dilakukan oleh Johan et al. (2018) pada kelompok kontrol yang hanya diberi aquades selama 28 hari menunjukkan histologi hepar yang normal, namun ditemukan pula degenerasi hidropik dan nekrosis dalam jumlah lebih sedikit daripada P1 dan P2. Hasil menunjukkan adanya perbedaan yang signifikan antara kelompok kontrol dengan kelompok P1 dan P2 sebesar $(\mathrm{p}<0,05)$. Perbedaan terlihat jelas antara kelompok kontrol dan kelompok perlakuan.

Gambaran mikroskopis histologi hepar pada kelompok pemberian dosis MSG dosis $5 \mathrm{~g} / \mathrm{kg}$ BB (P1) menunjukkan jumlah abnormalitas sel sebesar 40,5 (40- 
43)\% dengan kerusakan sedang, ditemukannya degenerasi lemak dan kongesti sinusoid. Hal ini menunjukkan kerusakan yang besar dibandingkan dengan kelompok kontrol. Penelitian ini sesuai dengan penelitian yang dilakukan oleh Setiani et al. (2016) menggunakan MSG dosis 173,6 mg/g BB/hari menyebabkan kerusakan hepatosit berupa perlemakan hati mikrovesikular dan peradangan sel. Berbeda halnya dengan penelitian yang dilakukan oleh Johan et al. (2018) dengan dosis MSG $4 \mathrm{~g} / \mathrm{kg} \mathrm{BB}$ dan $6 \mathrm{~g} / \mathrm{kg}$ BB selama 28 hari dan Andreas et al. (2015) dengan dosis $5 \mathrm{mg} / \mathrm{g}$ BB selama 28 hari, kedua penelitian ini menunjukkan adanya degenerasi hidropik dan nekrosis namun, tidak ditemukannya degenerasi lemak pada hepatosit.

Gambaran mikroskopis histologi hepar pada kelompok pemberian dosis MSG $10 \mathrm{~g} / \mathrm{kg}$ BB (P2) menunjukkan jumlah abnormalitas sel sebesar 52,5 (27$56) \%$ dengan kerusakan besar. Ditemukan degenerasi hidropik dan nekrosis dalam kondisi karioreksi. Hal ini sesuai dengan penelitian yang dilakukan oleh Johan et al. (2018) menggunakan MSG dosis $4 \mathrm{~g} / \mathrm{kg}$ $\mathrm{BB}$ dan $6 \mathrm{~g} / \mathrm{kg}$ BB selama 28 hari menyebabkan kerusakan hepatosit berupa degenerasi hidropik dan nekrosis. Degenerasi hidropik muncul karena ketidakmampuan sel dalam mempertahankan homeostatik ion dan cairan menyebabkan hilangnya fungsi pompa ion dependen energi pada membran sel (Maulina, 2018). Secara mikroskopik tampak vakuola kecil yang jernih di dalam sitoplasma yang menggambarkan segmen retikulum endoplasma yang menekuk dan berdistensi (Kumar et al., 2012).

Gambaran mikroskopis histologi hepar pada kelompok dosis MSG $15 \mathrm{~g} / \mathrm{kg}$ BB (P3) menunjukkan jumlah abnormalitas sel sebesar $60 \quad(59-62) \%$ dengan kerusakan besar. Ditemukan degenerasi lemak dan nekrosis dalam kondisi piknosis. Sejalan dengan penelitian yang dilakukan oleh Ermayanti et al. (2014), dengan dosis MSG 4,5 mg/g BB selama 35 hari terlihat adanya degenerasi bengkak keruh dan hidropik, selain itu terjadi perubahan lebih signifikan ditandai munculnya degenerasi lemak dan kerusakan sel yang menjurus ke arah nekrosis. Adanya degenerasi lemak pada hepatosit disebabkan karena peningkatan peroksida lipid sehingga mengganggu sintesis protein yang mengakibatkan penumpukan trigliserida (Ermayanti et al., 2014).

MSG dapat mengubah fungsi mitokondria sebagai respirasi sel. Kerusakan mitokondria diduga dapat menyebabkan anoksia sel sehingga timbul oksidasi sel yang dapat menyebabkan perlemakan hepatosit (Setiani et al., 2016). Hipoksia merupakan keadaan defisiensi oksigen yang mengakibatkan penurunan respirasi oksidatif aerob pada sel sehingga terjadi kerusakan sel. Hipoksia secara umum dapat menyebabkan cidera dan kematian sel tergantung dari beratnya keadaan hipoksia (Kumar et al., 2012)(Kumar, V., Ramzi, SC., Stanley, 2012). Secara klinis hipoksia disebut juga anoksia. Anoksia jaringan merupakan gangguan defisiensi oksigen yang terjadi di dalam jaringan sendiri, sehingga oksigen tidak dapat digunakan secara efektif (Amir, 2008).

Kerusakan awal hepatosit Tikus Wistar seperti pada kelompok P1 ditandai dengan terbentuknya sitoplasma granuler. Sitoplasma granuler merupakan kerusakan sementara yang dapat kembali normal jika pajanan dihentikan, kemudian kerusakan berlanjut menjadi degenerasi dan nekrosis 
(Delina, 2018). Degeneraasi merupakan kerusakan sel yang bersifat non letal dan sel dapat kembali seperti semula jika pajanan dihentikan, sedangkan nekrosis merupakan kerusakan yang bersifat permanen menyebabkan kematian sel. Efek toksik MSG dimulai dari rusaknya membran sel, dilanjutkan dengan rusaknya inti sel yang menyebabkan fungsi dan struktur sel tidak normal dan secara terus menerus mengakibatkan terjadinya nekrosis (Agverianti et al., 2020).

Kongesti muncul pada tiga kelompok perlakuan. Kongesti merupakan pembendungan darah akibat terganggunya aliran darah balik vena pada sinusoid. Kongesti hepatik akut pada vena sentralis dan sinusoid dapat menggelembung oleh darah bahkan menyebabkan degenerasi hepatosit sentral, hepatosit periportal, teroksigenasi lebih baik karena berdekatan dengan anteriol hepatika, mengalami hipoksia ringan dan perlemakan. Kongesti hepatik pasif kronis dapat mengakibatkan nekrosis sentrilobular disertai dengan hilangnya hepatosit serta perdarahan (Kumar et al., 2012).

\section{KESIMPULAN}

Pemberian MSG dosis $5 \mathrm{~g} / \mathrm{kg}$ BB menyebabkan degenerasi lemak dan kongesti sinusoid, dosis $10 \mathrm{~g} / \mathrm{kg} \mathrm{BB}$ menyebabkan degenerasi hidropik dan nekrosis dalam kondisi karioreksi, serta dosis $15 \mathrm{~g} / \mathrm{kg} \mathrm{BB}$ menyebabkan degenerasi lemak dan nekrosis dalam kondisi piknosis. Pemberian MSG dosis $15 \mathrm{~g} / \mathrm{kg}$ BB selama 14 hari menunjukkan kerusakan sel hepar paling signifikan sebesar 60 (59-62)\%.

\section{SARAN}

Perlu adanya penelitian lebih lanjut dengan memperpanjang lama waktu pemberian MSG, cara pengukuran sel seperti skneolesi, serta memperbanyak jumlah lapang pandang.

\section{UCAPAN TERIMA KASIH}

Terimakasih kepada dosen, rekan, dan staf laboratorium yang telah membantu dan memberi arahan selama penelitian.

\section{DAFTAR PUSTAKA}

Agverianti, T., Muhartono., Khairun, N. 2020. Pengaruh pemberian ekstrak etanol rimpang lengkuas (Alpinia galanga) terhadap gambaran histopatologi hepar mencit (Mus musculus L.) yang diinduksi monosodium glutamate. JIMKI, 7(2), pp. 7-13.

Andreas, H., Heru, F. T., Muhammad, I.I. 2015. Gambaran histologi regenerasi hati pasca penghentian pajanan monosodium glutamate pada tikus wistar. eJKI. 3 (1): 29-36.

Andriani. 2017. Pengaruh pemberian monosodium glutamat terhadap kadar hormon estradiol dan kadar hormon progesteron pada tikus putih betina (Rattus norvegicus ), JURNAL IPTEKS TERAPAN. 12(1), pp. 53-63.

Amir, A. 2008. Rangkaian Ilmu Kedokteran Forensik. Edisi ketiga. Bagian Forensik Fakultas Kedokteran Universitas Sumatera Utara, Medan.

Dahlan, M. S. 2009. Statistik untuk Kedokteran dan Kesehatan. Edisi 13. Jakarta: Salemba Medika.

Delina, S. 2018. Pengaruh monosodium glutamat ( MSG ) terhadap histopatologi hepar tikus putih jantan ( Rattus novergicus ) strain sprague dawley. Jurnal 'Aisyiyah 
Medika. 1(2), pp. 178-190.

Ermayanti, N.G.A.M., Dwi, A.Y., Ni Wayan, S. 2014. Struktur Histologi Hati Mencit ( Mus musculus L .) Setelah Perlakuan Monosodium Glutamat ( MSG ), in. Jimbaran: Jurusan Biologi Fakultas MIPA Universitas Udayana, pp. 298-303.

Johan, A.P., Muhammad, I.I., Mitra, H., Nawangsari., Sari, E.P. 2018. Gambaran histopatologi dan kemampuan regenerasi hepar tikus wistar jantan dewasa pasca penghentian pajanan monosodium glutamat. Jurnal Cerebellum. 4(4), pp. 1163-1175.

Kumar, V., Ramzi, S.C., Stanley, L.R. 2012. Buku Ajar Patologi Robbins. Edisi 7. Jakarta: Penerbit Buku Kedokteran EGC.

Maidawilis. 2010. Pengaruh pemberian monosodium glutamat terhadap kadar follicle stimulating hormon dan luteinizing hormon mencit (Mus musculus) betina strain Jepang. Tesis. Universitas Andalas Padang.

Maulina, M. 2018. Zat-Zat yang Mempengaruhi Histopatologi Hepar. Lhokseumawe: Unimal Press.

Menteri Kesehatan Republik Indonesia. 2014. Peraturan Menteri Kesehatan Nomor 41 Tahun 2014 tentang Pedoman Gizi Seimbang, Research Policy. Indonesia.

Muntaza, Y. \& Annis, C. A. 2020. Hubungan Sumber Informasi dan Pengalaman dengan Tingkat Pengetahuan tentang Penggunaan Monosodium Glutamate (MSG) pada Ibu Rumah Tangga. Amerta
Nutrition. 4(1), pp. 72-78.

Nurdin, N. \& Utomo, B. 2018. Tinjauan penggunaan bahan tambahan pangan pada makanan jajanan anak sekolah. Jurnal Riset Kesehatan. 7(2), pp. 85-90.

Pamelia, I. 2018. Perilaku konsumsi makanan cepat saji pada remaja dan dampaknya bagi kesehatan. Jurnal IKESMA. 14(2), pp. 144-153.

Rangkuti, R. H., Edy, S. \& Poppy, A.Z.H. 2012. Pengaruh pemberian monosodium glutamat (MSG) pada pembentukan mikronukleus sel darah merah mencit. Journal of Pharmaceutics and Pharmacology. 1(1), pp. 29-36.

Setiani, N. N. G. and Lily, Loho., Poppy, L. 2016. Gambaran histopatologik hati tikus wistar ( Rattus norveginus ) yang diinduksi monosodium glutamate ( msg ) dan diberikan sari air bawang daun ( Allium fistulosum L .) Jurnal e-Biomedik (eBm), 4(2).

Sukmaningsih, A.A.Sg.A., I Gusti, Ayu Manik Ermayanti., Ngurah, Intan Wiratmi., Ni Wayan, S. 2014. Gangguan spermatogenesis setelah pemberian monosodium glutamat pada mencit (Mus musculus L.). Jurnal Biologi. XV(2), pp. 49-52.

Tobi, H.A. 2013. Masak Sehat dengan Bumbu Penyedap (MSG). PT. Gramedia Pustaka Utama, Jakarta.

Wasilah, F.W. 2016. Pengaruh pemberian MSG (monosodium glutamat) terhadap kadar ureum dan kreatinin serum (fungsi ginjal) pada tikus betina sprague dawley usia 8-12 minggu. Skripsi. Universitas Islam Negeri Syarif Hisayatullah Jakarta. 


\section{Tabel 01}

\section{Efek MSG Terhadap Gambaran Histologi Hepar Tikus Putih (Rattus norvegicus) Galur Wistar}

\begin{tabular}{cccc}
\hline Dosis MSG & $\begin{array}{c}\text { Jumlah } \\
\text { Sampel }\end{array}$ & $\begin{array}{c}\text { Abnormalitas sel (\%) } \\
\text { Median (Minimum- } \\
\text { Maksimum) }\end{array}$ & P value \\
\hline $0 \mathrm{~g} / \mathrm{kg} \mathrm{BB}$ & 4 & 0 & \\
$5 \mathrm{~g} / \mathrm{kg} \mathrm{BB}$ & 4 & $40,5(40-43)$ & 0,034 \\
$10 \mathrm{~g} / \mathrm{kg} \mathrm{BB}$ & 4 & $52,5(27-56)$ & \\
$15 \mathrm{~g} / \mathrm{kg} \mathrm{BB}$ & 3 & $60(59-62)$ & \\
\hline
\end{tabular}

Keterangan: uji Kruskal-Wallis dengan post hoc Mann-Whitney U: kelompok kontrol vs kelompok P1 p=0,013. Kelompok kontrol vs kelompok P2 p=0,014. Kelompok kontrol vs kelompok P3 p=0,019. Kelompok P1 vs kelompok P3 $\mathrm{p}=0,032$. Kelompok P2 vs kelompok P3 p=0,034. Data disajikan dalam Median (Minimum-Maksimum).

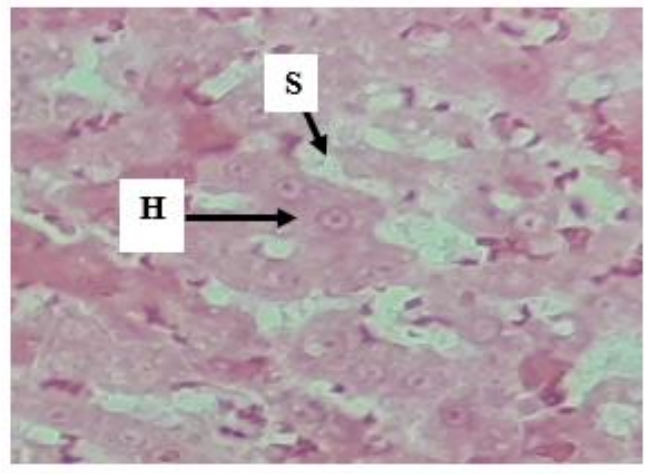

A (Kontrol)

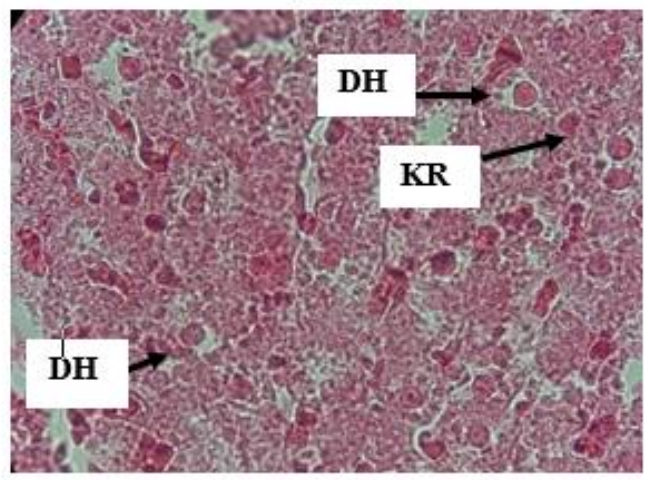

$\mathrm{C}$ (P2)

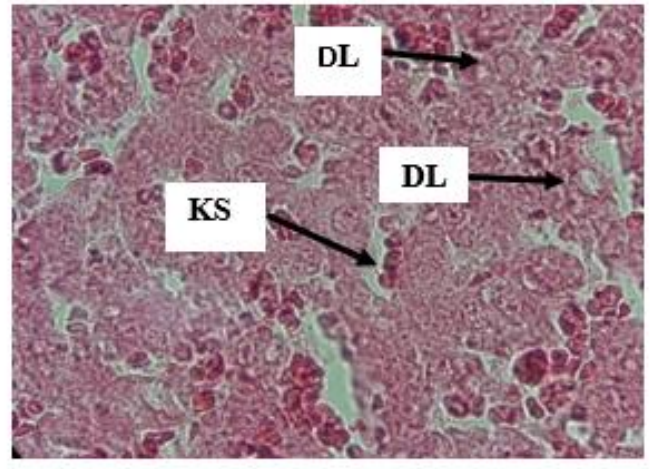

B (P1)

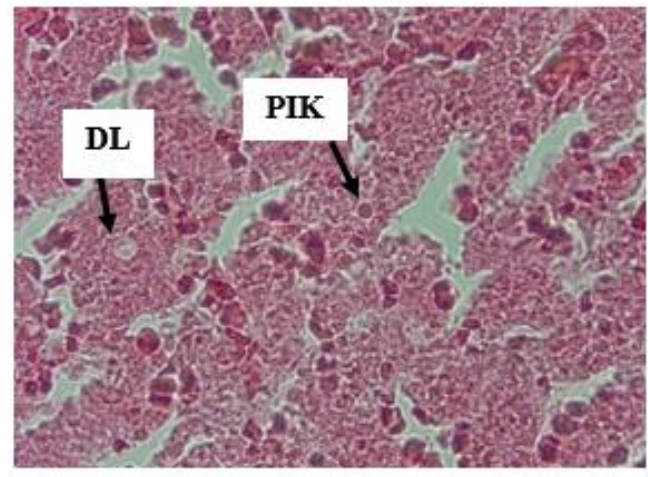

$\mathrm{D}$ (P3)

Gambar 1

Histologi Hepar Tikus Putih (Rattus norvegicus) Galur Wistar dengan pewarnaan HE dan perbesaran $100 \times 10$.

Keterangan: A (Kontrol): sel hepatosit normal (H) dan sinusoid (S). B (P1): dosis MSG $5 \mathrm{~g} / \mathrm{kg}$ BB degenerasi lemak (DL) dan kongesti sinusoid (KS). C (P2): dosis MSG $10 \mathrm{~g} / \mathrm{kg}$ BB degenerasi hidropik (DH) dan karioreksis (KR). D (P3): dosis MSG $15 \mathrm{~g} / \mathrm{kg}$ BB piknosis (PIK) dan degenerasi lemak (DL). 